\title{
PROGRAM KEMITRAAN MASYARAKAT (PKM) KELOMPOK USAHA PERBENGKELAN KECAMATAN MANGGALA KOTA MAKASSAR
}

\author{
Asmeati $^{1}$, Nina Fapari Arif ${ }^{2}$
}

\begin{abstract}
ABSTRAK
Bengkel adalah usaha yang berkembang pesat dan sangat menunjang diera perkembangan industri saat ini. Mitra dalam kegiatan PKM ini yaitu usaha bengkel mobil yang bertempat di Jl..Tamangapa Raya Kota Makassar. Permasalahan yang dihadapi mitra tingginya tingkat persaingan, Sehingga di tuntut untuk melakukan perencanaan dan strategi untuk menghasilkan keunggulan bersaing. Solusi yang ditawarkan adalah : 1). Pelatihan desain dalam meningkatkan inovasi produk yang lebih beragam, 2). Pelatihan pembuatan produk dengan desain yang lebih inovatif, 3). Pelatihan dan penerapan Keselamatan dan Kesehatan Kerja (K3) agar dapat bekerja dalam kondisi yang sehat, nyaman, dan aman sehingga dapat terus mendorong produktivitas usaha, 4).Pelatihan manajemen usaha yang bertujuan usaha tidak akan mudah goyah atau mengalami ketidakseimbangan dan 5). Pelatihan manajemen pemasaran dalam memperluas jangkauan. Rencana kegiatan ini akan dilaksanakan selama 8 (delapan) bulan. Selain itu, dalam pelatihan ini peserta terdiri dari 10 orang. Hasil yang diperoleh dari kegiatan ini adalah : Sumber daya manusia yang lebih terampil dalam membuat desain produk yang lebih beragam dan inovatif.
\end{abstract}

Kata kunci : desain, bengkel, K3, sumber daya manusia, pemasaran

\begin{abstract}
Repair shop is a business that is growing rapidly and is very supportive in the current era of industrial development. The partners in this PKM activity are car repair shops located on J1.Tamangapa Raya Makassar City. Problems faced by partners are high levels of competition, so it is demanded to carry out planning and strategies to produce competitive advantage. The solutions offered are: 1). Design training in enhancing product innovation that is more diverse, 2). Training on making products with more innovative designs, 3). Training and application of Occupational Safety and Health (K3) in order to work in healthy, comfortable, and safe conditions so as to continue to encourage business productivity, 4). Business management training aimed at businesses will not be easily swayed or experience an imbalance and 5). Marketing management training in expanding outreach. This activity plan will be carried out for 8 (eight) months. In addition, in this training participants consisted of 10 people. The results obtained from this activity are: Human resources who are more skilled in making product designs that are more diverse and innovative.
\end{abstract}

Keywords: design, repair shop, human resources, marketing

\footnotetext{
${ }^{1}$ Dosen Program Studi Teknik Mesin, Fakultas Teknik, Universitas Fajar, Makassar, asmeati@ unifa.ac.id ${ }^{2}$ Dosen Program Studi Manajemen, Fakultas Ekonomi dan Ilmu-ilmu Sosial, Universitas Fajar, Makassar, ninafapari@unifa.ac.id
} 


\section{PENDAHULUAN}

Perkembangan dunia industri di Indonesia mengalami peningkatan yang pesat. Industri adalah suatu usaha atau kegiatan pengolahan bahan mentah atau barang setengah jadi menjadi barang jadi, barang yang memiliki nilai tambah untuk mendapatkan keuntungan. Hasil industri tidak hanya berupa barang, tetapi juga dalam bentuk jasa. Perkembangan industri sangat berpengaruh kepada usaha perbengkelan termasuk bengkel las.

Usaha pengelasan merupakan usaha informal yaitu usaha yang memiliki pola kegiatan tidak teratur, baik dalam arti waktu, permodalan maupun penerimaannya serta pada umumnya tidak tersentuh oleh peraturan dan ketentuan yang ditetapkan. Perkembangan industri ini tidak dapat dilepaskan dari peran penting industri pengelasan. Pengelasan adalah penyambungan setempat antara dua buah logam atau lebih dengan memanfaatkan energi panas. Penggunaan pengelasan mulai dari penyambungan pada konstruksi bangunan, perakitan otomotif dan penambangan. Pesatnya industri pengelasan mengakibatkan semakin tingginya dampak resiko pada kesehatan kerja yang dihadapi oleh tenaga kerja di bengkel las.

Kondisi lingkungan kerja yang dapat menyebabkan resiko bahaya merupakan kondisi lingkungan kerja yang tidak memenuhi syarat keselamatan dan kesehatan kerja (K3), proses kerja tidak aman, dan sistem kerja yang semakin komplek dan modern dapat menjadi ancaman tersendiri bagi keselamatan dan kesehatan pekerja.

Dari hasil wawancara dengan mitra Lapak Kreatif yang bergerak dibidang pengelasan beralamat di Jl. Jipang raya kota Makassar (awal April 2019) diperoleh kesimpulan bahwa usaha ini pun semakin menjanjikan karena semakin tingginya pembangunan maka jasa pengelasan semaki diperlukan. Namun seiring dengan semakin ketatnya persaingan dunia usaha, UMKM ini dituntut agar mampu menyediakan produk lebih inovatif dan unggul. Namun, fakta di lapangan menunjukkan masih terdapat beberapa kelemahan produk mitra yakni desain produk yang dihasilkan kurang inovatif sehingga ada ketidak puasan pelanggan, kurangnya manajemen dalam tata kelolah usaha dan pemasaran. Berdasarkan pengamatan pada mitra dimana kurangnya penerapan keselamatan dan kesehatan kerja (K3). Penerapan K3 dianggap penting untuk menciptakan kondisi aman, nyaman dalam melakukan pekerjaan. Maka dalam kegiatan ini pula akan diadakan pelatihan Keselamatan dan Kesehatan Kerja (K3).

Berdasarkan analisis situasi yang telah dilakukan oleh Tim PKM diketahui bahwa terdapat beberapa kelemahan pada hasil panen masyarakat khususnya pada hasil panen buah. Kegiatan PKM ini dilakukan terhadap mitra yang memiliki hasil panen buah. adapun permasalahan yang dialami : (1). Inovasi produk yang dihasilkan masih terbatas, (2). Kurangnya penerapan K3 dalam melakukan pekerjaan, (4). Manajemen usaha yang masih kurang, dan (5). Pemasaran masih terbatas sehingga kurang menjangkau kawasan yang luas.

Bengkel las khususnya untuk pembuatan pagar, teralis, kanopi dan konstruksi lainnya memang cukup potensial ketika masyarakat sekarang ini sudah semakin modern dalam membuat inovasi desain serta rancangan struktur dan aksesoris bangunannya. Baik didesa maupun di kota, usaha bengkel las seakan tiada matinya dan bahkan semakin berkembang meskipun selalu bermunculan pengusaha sejenis yang membuka jasa pekerjaan yang berhubungan dengan besi ini ( $\mathrm{T} \&$ Fatah, n.d.). Tidak dapat dipungkiri, bahwa pesatnya pembangunan telah turut mendorong terbukanya peluang usaha bagi para pelaku bisnis baru atau pemain lama yang semakin melebarkan sayapnya.

Dari hasil penelitian ketajaman penglihatan oleh (Trisnowiyanto, 2002) terhadap pekerja pengelasan listrik di Pasar Semanggi, Surakarta, didapatkan intensitas cahaya las sebesar 289,7348,0 luks, sebesar 23,08\% responden mengalami gangguan ketajaman penglihatan dan $30 \%$ responden mengalami konjungtivitis.

Berdasarkan data Badan Penyelenggara Jaminan Sosial (BPJS) Ketenagakerjaan di Indonesia telah terjadi 105.182 kasus kecelakaan kerja hingga akhir tahun 2015 yang dikutip dalam (Kementrian Kesehatan RI, 2018). Dimana 2.375 kasus dari total jumlah kecelakaan kerja merupakan kasus kecelakaan berat yang mengakibatkan kematian. Angka kecelakaan kerja tersebut relatif sangat tinggi. Penyebab kecelakaan kerja yang sering ditemui diantaranya perilaku 
yang tidak aman, kondisi lingkungan yang tidak aman, atau kedua kondisi tersebut terjadi secara bersama - sama. Kesehatan dan keselamatan kerja di perusahaan bertujuan agar dapat bekerja dalam kondisi yang sehat, nyaman, dan aman sehingga dapat terus mendorong produktivitas usaha. Untuk itu, diperlukan kemauan, komitmen, dan dalam penerapan K3 ini.

\section{METODE PELAKSANAAN}

Secara garis besar, solusi yang ditawarkan dalam rangka menjawab permasalahan produksi dari UMKM adalah sebagai berikut:

\section{Metode Pendekatan}

Kegiatan PKM ini akan menggunakan beberapa metode sebagai berikut:

1. Metode pelatihan inovasi dalam meningkatkan produk aneka barang dan jasa yang libih beragam.

2. Metode pelatihan dan penerapan "Keselamatan Kesehatan Kerja (K3)", agar dapat bekerja dalam kondisi yang sehat, nyaman, dan aman sehingga dapat terus mendorong produktivitas usaha.

3. Metode Pengenalan "Aplikasi Electronic Control Unit", untuk meningkatkan kualitas dan kuantitas kinerja dari Mitra tersebut.

4. Metode pelatihan operasionalisasi "Aplikasi Electrical Control Unit", agar UMKM mitra lebih lancar dalam mengoperasikan alat

5. Metode pelatihan manajemen dalam pengelolaan usaha

6. Metode pelatihan strategi pemasaran yang lebih luas.

\section{Partisipasi Mitra}

Partisipasi mitra dalam pelaksanaan program PKM ini adalah mengikuti pelatihan dan pendampingan, serta mengajak kedua mitra yakni Lapak Kreatif dan Fajar Motor untuk mengikuti kegiatan pelatihan dan pendampingan dan diharapkan kerjasama dalam menyiapkan tempat pelatihan, kesediaan mengikuti semua kegiatan, pendokumentasian proses produksi, motivasi yang tinggi dimiliki mitra untuk mengembangkan usaha, hal ini ditunjukkan keaktifannya dalam diskusi dalam merancang penyelesaian permasalahan yang akan ditangani. Dengan demikian, kegiatan PKM akan sangat bermanfaat bagi mitra. Tempat kegiatan ini berlangsung adalah di bengkel Lapak Kreatif dan Fajar Motor. Kegiatan ini berlangsung dari bulan April sampai dengan November 2019. Jumlah peserta dari 1 mitra adalah 5 orang. Jadi total peserta adalah 10 orang.

\section{HASIL DAN PEMBAHASAN}

Rencana Tahapan Kegiatan

Pelaksanaan kegiatan PKM yang telah disepakati bersama antara TIM PKM

UNIFA dan UMKM Mitra adalah sebagai berikut:

1. Koordinasi dengan Dinas Perindustrian dan Perdagangan, serta Dinas Tenaga Kerja dan Transmigrasi Kota Makassar. Hal ini diperlukan, agar pasca kegiatan pelatihan dan pendampingan selesai, kedua dinas terkait tersebut yang akan membantu mengembangkan pasar aneka produk.

2. Metode pelatihan inovasi dalam meningkatkan produk aneka barang dan jasa yang lebih beragam.

3. Pelatihan dan penerapan "Keselamatan Kesehatan Kerja (K3)".

4. Pengenalan "Aplikasi Electrical Control Unit".

5. Pelatihan operasionalisasi "Aplikasi Electrical Control Unit".

6. Pelatihan manajemen dalam pengelolaan usaha

7. Pelatihan strategi pemasaran

\section{Hasil Kegiatan}

Hasil Kegiatan PKM ini telah dilaksanakan sebagai berikut: 
1. Pelatihan desain dalam meningkatkan inovasi aneka produk lebih beragam.

2. Pembuatan produk dengan desain yang lebih inovatif.

3. Pelatihan dan penerapan "Keselamatan Kesehatan Kerja (K3)", agar dapat bekerja dalam kondisi yang sehat, nyaman, dan aman sehingga dapat terus mendorong produktivitas usaha.

4. Pelatihan manajemen dalam pengelolaan usaha.

5. Pelatihan strategi pemasaran yang lebih luas.

Pentingnya pelatihan desain, pembuatan produk dan K3 diharapkan mampu menjadi pemacu daya kreativitas peserta yang ikut dalam kegiatan ini. Kreavitas bukanlah yang mudah untuk diwujudkan dan dikaji. Hal ini dikarenakan setiap orang memiliki tingkat kreativitas yang berbeda. Kreativitas dapat dipahami sebagai kapabilitas yang dapat digunakan untuk mengembangkan dan mengubah gagasan, proses, mode, model, pelayanan dan perilaku tertentu. Hubungan antara inovasi dan kreativitas itu sendiri sangat dekat. Oleh karena itu dapat dipahami bahwa secara sederhana inovasi adalah proses pengenalan cara baru dan lebih baik dalam mengerjakan beberapa hal yang harusnya terjadi dalam masyasrakat.

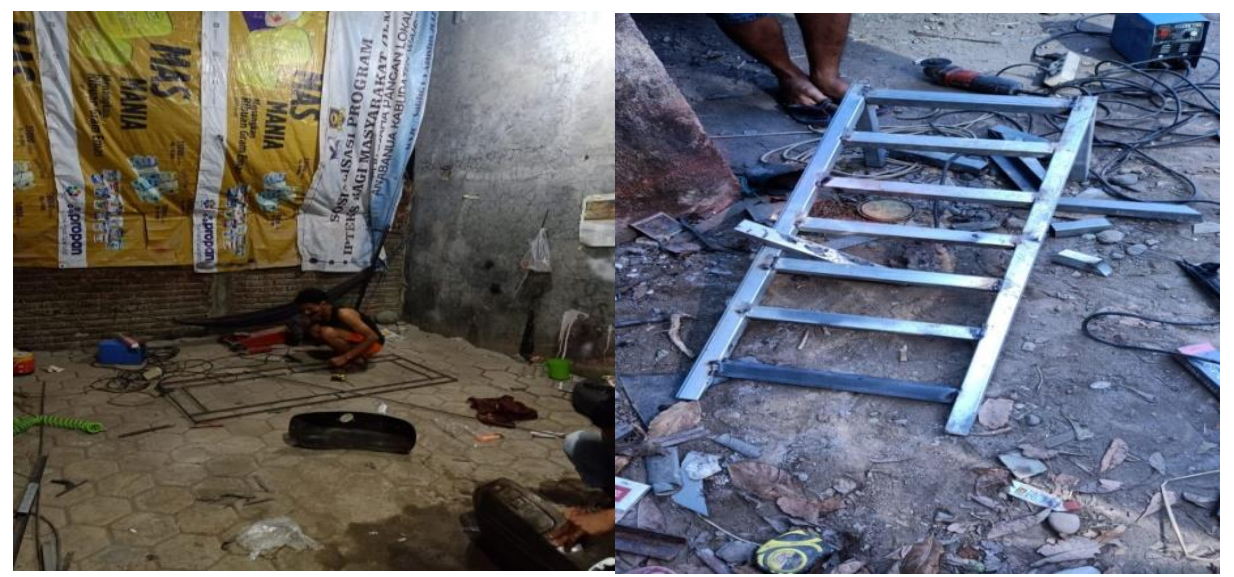

Gambar 1. Proes pelaksanaan pengelasan

\section{Evaluasi}

Evaluasi dan monitoring hasil pelaksanaan kegiatan PKM yang telah dilaksakan bersama antara TIM PKM UNIFA dan UMKM Mitra meliputi pelatihan dan pendampingan dalam peningkatan inovasi, kualitas dan pemasaran dalam peningkatan penjualan produk/barang dan jasa yang ditawarkan.

\section{KESIMPULAN}

Kesimpulan yang didapatkan setelah melakukan kegiatan pengabdian ini adalah berdasarkan hasil evaluasi ke pihak mitra dapat di lihat adanya keseriusan untuk mengikuti kegiatan. Dengan adanya pelatihan manajemen usaha membuat usaha mitra berkembang lebih baik. Sumber daya manusia yang lebih terampil dalam membuat desain produk yang lebih beragam dan inovatif. Selain itu, mitra juga telah mampu untuk membuat desain yang lebih berbeda dan menjual bagi konsumen.

\section{UCAPAN TERIMA KASIH}

Terima kasih penulis ucapakan kepada Kementrian Ristek DIKTI yang telah meloloskan dan membiayai kegiatan PkM melalui pendanaan DPRM. Selain itu ucapan terima kasih dihaturkan kepada pihak LPPM Universitas Fajar yang telah memberikan asistensi dan bantuan dalam pelaksanaan kegiatan ini.

\section{DAFTAR PUSTAKA}


Kementrian Kesehatan RI. (2018). Info Datin Keselamatan Dan Kesehatan Kerja.

T, P., \& Fatah, A. (n.d.). IbM PENGEMBANGAN USAHA BENGKEL LAS. SEMINAR NASIONAL, 1-4. Trisnowiyanto, B. (2002). BEBERAPA FAKTOR YANG BERHUBUNGAN DENGAN KETAJAMAN PENGLIHATAN PEKERJA LAS LISTRIK DI PASAR BESI TUA SEMANGGI SURAKARTA TAHUN 2002. Diponegoro University. 